http://www.anpad.org.br/bar

BAR, Rio de Janeiro, v. 11, n. 2, art. 3, pp. 164-187, Apr./June 2014

\title{
Ability-Based View in Action: A Software Corporation Study
}

Farley Simon Nobre

E-mail address: fsmnobre@gmail.com Universidade Federal do Paraná - PPGADM/UFPR DAGA/UFPR, Av. Pref. Lothario Meissner, 632, 80210-170, Curitiba, PR, Brazil.

David Walker

E-mail address: d.s.walker@bham.ac.uk The University of Birmingham Business School The University of Birmingham Business School, Edgbaston, Birmingham B15 2TT, UK.

Michael Brown

E-mail address: Mike.Brown@bcu.ac.uk Birmingham City Business School Birmingham City University, Perry Barr, Birmingham, B42 2SU, UK.

Received $2^{\text {nd }}$ March 2013; received in revised form 11 August 2013 (this paper has been with the authors for two revisions); accepted $4^{\text {th }}$ October 2013; published online $1^{\text {st }}$ April 2014. 


\begin{abstract}
This research investigates antecedents, developments and consequences of dynamic capabilities in an organization. It contributes by searching theoretical and empirical answers to the questions: (a) What are the antecedents which can provide an organization with dynamic and ordinary capabilities?; (b) How do these antecedents contribute to create capabilities in an organization?; (c) How do they affect an organization's competitive advantage?; (d) Can we assess and measure the antecedents and consequences to an organization? From a first (theoretical) perspective, this paper searches answers to the first, second and third questions by reviewing concepts of an ability-based view of organizations that involves the abilities of cognition, intelligence, autonomy, learning and knowledge management, and which contributes to explain the dynamic behavior of the firm in the pursuit of competitive advantage. From a second (empirical) perspective, this paper reinforces and delivers findings to the second, third and fourth questions by presenting a case study that evidences the abilitybased view in action in a software corporation, where it contributes by investigating: (a) the development of organizational capabilities; (b) the effects of the new capabilities on the organization; and (c) the assessment and measurement of the abilities and consequences.
\end{abstract}

Key words: ability-based view; core competencies; dynamic capabilities; software capability maturity model. 


\section{Introduction}

In a similar way to that in which Simon (1977) distinguished between non-programmed and programmed decisions, March and Simon (1958) distinguished higher-level and lower-level programs (and routines), Argyris and Schön (1978) distinguished double-loop and single-loop learning, and March (1991) distinguished knowledge exploration and exploitation, advancements in the field of strategic management have distinguished the concepts of dynamic and operational capabilities (Eisenhardt \& Martin, 2000; Helfat \& Peteraf, 2003, 2009; Helfat \& Winter, 2011; Leiblein, 2011; Sirmon, Hitt, Ireland \& Gilbert, 2011; Teece, 2007; Teece, Pisano, \& Shuen, 1997; Winter, 2003). The first concept has been associated with the firm capabilities of renewal, management and orchestration of resources and operational capabilities, and is also associated with the organizational capacity to solve ill-structured or complicated problems, to learn, change and adapt to turbulent and complex environments. Examples of dynamic capabilities include sensing-seizing-reconfiguring (Teece, 2007) along with sensing-learning-integrating-coordinating capabilities (Pavlou \& El Sawy, 2011). Most of these dynamic capabilities are developed from cognitive processes and representations at the individual, group and organizational levels (Nobre, Tobias, \& Walker, 2010; Nobre \& Walker, 2011a, $2011 b$ ). The second concept has the meaning of ordinary competencies, processes and basic routines of standardized and repetitive patterns which can find better applications to well-structured situations with predetermined decision rules. Examples of operational capabilities involve activities such as manufacturing a product, inspection procedures and quality assurance norms. Additionally, capabilities are built on different levels of organizational activity, for instance at departmental, divisional, or corporate levels (Schreyögg \& Kliesch-Eberl, 2007).

This paper supports all these developments. Nevertheless, as emphasized by other authors (Wang \& Ahmed, 2007), this work recognizes the existence of ambiguity in the concepts of the main elements within the vast literature of dynamic capabilities. Moreover, it advocates there is a lack of literature perspectives which contribute with measurements in dynamic capabilities and general management research (Scherbaum \& Meade, 2013). In light of contribution to these concerns, this research investigates antecedents, developments and consequences of dynamic capabilities in organizations that pursue competitive advantage. It searches for theoretical and empirical answers to the questions: (a) What are the antecedents which can provide an organization with dynamic and ordinary capabilities?; (b) How do these antecedents contribute to create organizational capabilities?; (c) How do they affect an organization's competitive advantage?; (d) Can we assess and measure the antecedents and consequences to an organization? From a first (theoretical) perspective, this paper searches for answers to the first, second and third questions by reviewing concepts of an ability-based view that nourishes the development of core competencies and capabilities in an organization. From a second (empirical) perspective, this paper reinforces and delivers findings to the second, third and fourth questions by presenting a case study in order to investigate: (a) the development of capabilities in the organization; (b) the effects of the new capabilities on the organization; and (c) the assessment and measurement of the abilities and consequences. The development of this paper is structured as follows: (a) key concepts of the ability-based view, (b) research methodology, (c) entering the field, (d) operational definitions of key constructs, (e) analyzing data and shaping hypotheses, (f) conclusions.

\section{Ability-Based View (ABV)}

Ability-Based View (ABV) represents a conceptual framework for the analysis of the antecedents of competencies and capabilities in organizations that pursue competitive advantage (Nobre et al., 2010; Nobre \& Walker, 2011a, 2011b). It is based mostly on the perspectives of resource (Barney, 1991; Barney, Ketchen, \& Wright, 2011) and knowledge-based views (Grant, 1996; Spender, 1996) along with dynamic capabilities (Teece, 2007; Teece et al., 1997) of the firm. The 
ABV's key concepts subsume abilities, core competencies and capabilities, resources and competitive advantage. Their conceptual definitions along with the ABV framework are presented in the subsequent subsections.

\section{ABV's key concepts}

\section{Competitive advantage}

Competitive advantage involves a set of states which represent an organization's capability to create superior value for its customers and superior profits for itself. In such a view, the organization must conceive of value creating strategies that are not simultaneously being implemented by another competitor (Barney, 1991).

\section{Strategic resources}

Resources are inputs into an organization's production system and they involve tangible and intangible assets (Helfat \& Peteraf, 2003; Hitt, Ireland, \& Hoskisson, 2012; Teece, 2007). When integrated and coordinated in a proper manner, a set of resources can benefit the organization with efficiency, effectiveness and superior value. Resources can subsume competencies and capabilities (Barney, 1991). In this paper, resources are the set of organizational elements which involve social structure, goals, technology and participants (Scott, 1998), and, therefore, they can encompass competencies and capabilities.

\section{Core competencies and capabilities}

Tracing back to the seminal paper by Prahalad and Hamel (1990), this research understands that core competencies involve a set of collective knowledge in an organization, and including how to coordinate diverse production skills and integrate multiple streams of technologies. Core competencies are sources of innovation, customer benefits and competitive advantage (Hitt et al., 2012; Lei, Hitt, \& Bettis, 1996; Tidd, 2006). In this paper, they are treated as special classes of dynamic and ordinary capabilities (Nobre \& Walker, 2011a). They are capabilities which are valuable and unique from a customer's point of view, and also inimitable and non-substitutable from the competitor's eyes (Hitt et al., 2012).

Similarly to capabilities which can be built on different levels of organizational activity (Schreyögg \& Kliesch-Eberl, 2007), core competencies are developed on different levels of firm activity, such as at technical, managerial and organizational levels (Nobre, Walker, \& Harris, 2012); whereas at lower levels they are mostly equivalent to ordinary capabilities, at higher levels they mostly have the meaning of dynamic capabilities. Nevertheless, all these levels can involve ordinary and dynamic capabilities.

At the technical level for instance, ordinary capabilities would include the individual routines of hundreds of single manufacturing cells within a firm; dynamic capabilities would include processes of reconfiguration and combination of these cells in order to form an integrated and profitable production system. The same reasoning applies to the managerial and organizational levels; whereas elements, resources, competencies, capabilities, and so forth, can be reconfigured and integrated to create new strategies and value for the organization (Eisenhardt \& Martin, 2000; Teece et al., 1997). In such a design, managerial core competencies support the managerial layer when mediating and orchestrating resources between organizational and technical levels. Figure 1 illustrates the levels of core competencies and their linkages to capabilities. 


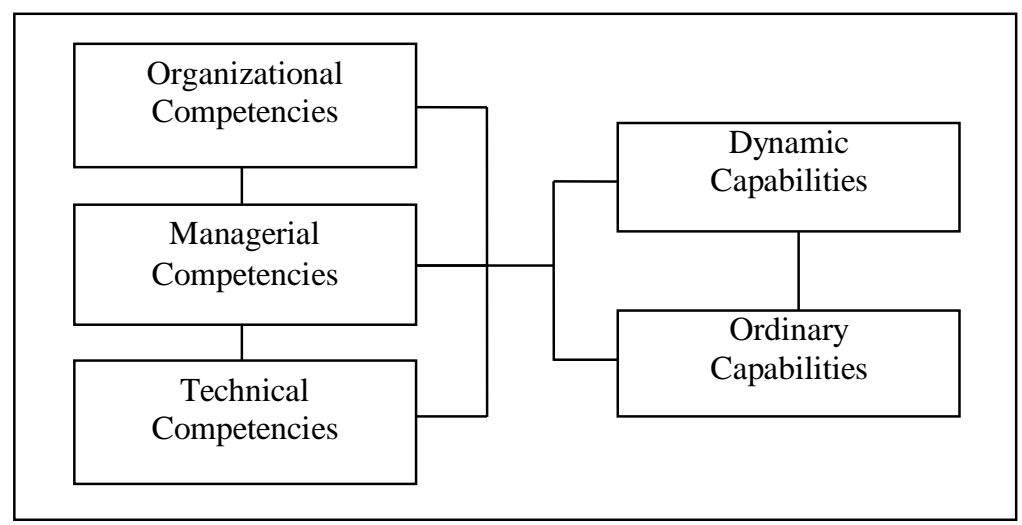

Figure 1. Core Competencies and Capabilities' Levels.

\section{Organizational abilities}

Abilities are distinct from competencies and capabilities because the former concept represents the antecedent and the source of development of the two latter concepts. Abilities involve cognition, intelligence, autonomy, learning and knowledge management, all of which are distinct but complementary concepts in the organization. Together these concepts form the set of abilities which are the sources of creation, management and orchestration of competencies and capabilities in organizations that pursue competitive advantage. Under such a view, cognition is the core ability which supports individuals, groups and organizations with the other abilities of intelligence, autonomy, learning and knowledge management (Nobre et al., 2010; Nobre \& Walker, 2011a, 2011b). These premises are also grounded in literature findings and empirical evidences which explain the role of managerial cognition in capability development (Gavetti, 2005; Laamanen \& Wallin, 2009; Tripsas \& Gavetti, 2000).

Definitions of the organizational abilities were developed and introduced in Nobre, Tobias, and Walker (2010) and, Nobre and Walker (2011b). Nevertheless, this subsection summarizes the concepts as used in this research.

\section{Cognition}

Cognition involves processes and representations in an organization (Nobre et al., 2010; Nobre, Tobias, \& Walker, 2009a; Nobre \& Walker, 2011b). On one side, when viewed as processes, cognition mediates the effect of external events or stimuli on individuals', groups' and organizations' decisions, behaviors and actions, in response to their experiences. On the other side, as representations, cognition is synonymous with mental images, knowledge models and cognitive maps constructed from individuals', groups' and organizations' experiences and learning. Representations have a major role in directing behavior in the absence of environmental stimuli (Brewer \& Hewstone, 2004).

\section{Intelligence}

Rational process or rationality is the ability to follow procedures for decision making and problem solving in the pursuit of goals (Simon, 1997a, 1997b). When rational processes lead individuals to satisfactory outcomes, rationality can be associated with intelligence. Therefore, in this paper, intelligence is associated with the degree to which an organization satisfies its goals through rationality. 


\section{Autonomy}

Autonomy is the ability of individuals, groups, and organizations to act through the use of cognition. Autonomous organisms are contingent upon cognition and therefore they are continuously attempting to improve their cognitive abilities.

\section{Learning}

Learning is the process of making changes in an organization's elements (goals, social structure, technology, and participants) and behavior through experience, cognition, emotion, and environmental stimuli, for organizational benefits. Such a perspective implies relationships with the effect of learning on cognition, and vice-versa.

\section{Knowledge management}

Knowledge management in organizations involves a set of practices and socially enacted processes for: (a) creation, including renovation and conversion (from tacit to explicit, and from explicit to tacit knowledge); (b) storage and retrieval; (c) transfer, exchange, and distribution; and (d) application of knowledge, either through individuals, groups or organizational processes and practices, for the benefit of the organization.

\section{ABV framework}

Figure 2 illustrates the $\mathrm{ABV}$ framework, which describes the dynamic behavior of the organization in the continuous pursuit of competitive advantage. In this figure, the lines which connect the elements of the framework indicate that the change or evolution of one element affects the others. The ABV framework's functional processes can be summarized by: (a) First, an organization interacts with the environment through its abilities in order to develop, renew, manage and orchestrate core competencies and capabilities which, in turn, are the means for the acquisition, exchange, processing, creation, storage, distribution, integration, reconfiguration and employment of new resources for the organization's benefit.

In such a process, the organization evolves and improves its cognition, intelligence, autonomy, learning and knowledge management abilities; (b) Second, improvements in organizational abilities, core competencies, capabilities and resources form the basis for the creation of an organization's competitive advantage; (c) Third, internal and external stimuli can affect an organization's competitive advantage, and, consequently, changes in the organization's competitive advantage will activate the organizational abilities in order to restart new cycles of development, renewal, management and orchestration of core competencies, capabilities, and resources, along with the creation of competitive advantage; (d) Processes (a) to (c) repeat continuously in order to reduce the level of environmental uncertainty (Nobre \& Walker, 2011a), and to improve an organization's abilities, core competencies, capabilities, resources, and competitive advantage.

\section{Environment}

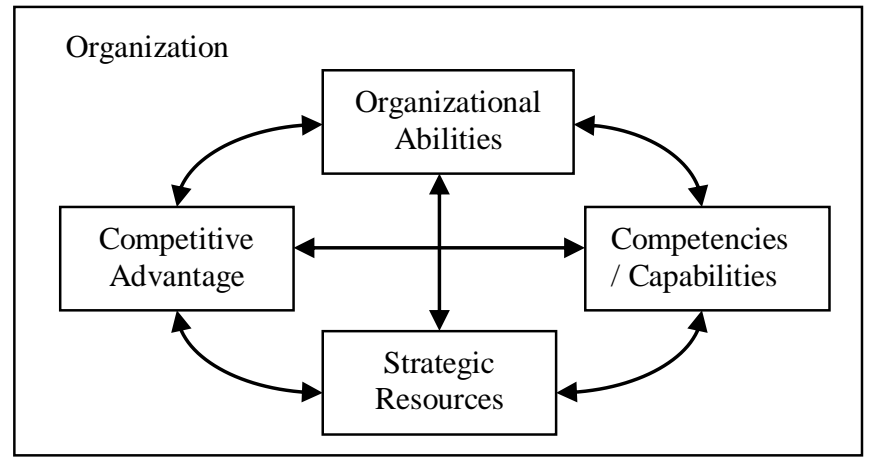

Figure 2. Ability-Based View (ABV) Framework. 


\section{Research Methodology}

\section{Strategy and methods}

This paper adopted a longitudinal case study research (Eisenhardt, 1989; Eisenhardt \& Graebner, 2007; Flyvbjerg, 2006), supported with the methods of participant observation, archival research and focus groups (Collis \& Hussey, 2009; Yin, 2011) along with cognitive mapping (Eden, 1992, 2004; Fiol \& Huff, 1992; Nicolini, 1999) and computational modeling (Nobre et al., 2009a, 2009b; Prietula, Carley, \& Gasser, 1998); in order to investigate: (a) the development of capabilities in the organization's software units; (b) the effects of the new capabilities on the organization; and (c) the assessment and measurement of the abilities and consequences.

\section{Case study selection: Alpha}

The investigation was conducted in a software corporation (Alpha) because its internal and external environments were characterized by technology and innovation intensiveness, and it was passing through regulatory, economic and political changes. In such a way, this company was working in the pursuit of competitive advantage in a turbulent and dynamic market; complex environments are attractive elements for the implementation of dynamic capabilities strategies (Pettus, Kor, \& Mahoney, 2009; Teece et al., 1997).

\section{Data collection instruments}

Participant observation was the path followed to perceive and interpret information about Alpha's internal and external environments. This approach was important to observe the phenomena under study as well as to gain familiarity with the group of participants in Alpha who were involved in software projects and software processes. Observations were mainly registered by participating in activities at Alpha's software units such as peer reviews; strategic management meetings; project planning, tracking and oversight; quality assurance audits; metrics design; laboratory and prototype tests; customers' reviews; process planning, tailoring and reconfiguration; and so forth. The gathered data also included notes about Alpha's elements such as social structure, goals, values, participants' motives and behavior, processes and technologies, procedures and routines, and so forth. These data were fundamental inputs to support analyses and to cross validate information with the other methods.

Archival research was mainly adopted to collect data from Alpha's software projects and software processes. The gathered data included software projects' requirements, functionalities, costs, schedules, technologies, and so forth; along with software processes' routines and subroutines at technical, managerial and organizational levels. These data were useful inputs to the conception, computation and analysis of Alpha's software capability and performance. They supported decisions in the approaches to focus groups, cognitive mapping and computational modeling. Most of the data of archival research were also synthesized in the publications of Nobre, Nakasone, Palhares, Madrid and Roy (2000) and Volpe, Nobre, Pessoa and Spinola (2000).

Focus groups were the approach to the social construction of cognitive maps, with participants including a total of 8 experts in software projects and software processes. In this approach, the concepts of customer satisfaction and project effectiveness were socially constructed through semistructured interview protocols and brainstorming. These concepts supported the analysis of Alpha's software performance.

Cognitive maps were socially constructed to represent linguistic concepts and mental models about customer satisfaction and project effectiveness. They also provided information about the relationships between antecedents and consequents of customer satisfaction and project effectiveness 
(Appendix, Figures A4 and A5); whereas such relations were important inputs to computational modeling.

Computational modeling was useful to generate metrics and measurements of customer satisfaction and project effectiveness which represented Alpha's performance indexes.

\section{Entering the Field}

Alpha was part of a multinational corporation which acted in the global information technology and communications, internet, and semiconductors market, along with other digital and technological fields. Alpha was located in Sao Paulo, Brazil, and acted in the Brazilian and world markets by providing governmental and private organizations with telecommunications services and technologies where performance is highly dependent on complex and large-scale software systems. Table 1 presents data about Alpha during the study period (Nobre et al., 2009a; Volpe, Nobre, Pessoa, \& Spinola, 2000).

Table 1

\section{Characteristics about Alpha: 1996-2001}

\begin{tabular}{ll}
\hline Foundation year & 1968 \\
Average Net Sales & US\$ 2,381.6 (millions) \\
End products & Radio, Transmission, Switching and Wireless Systems \\
Average number of employees & 2,932 \\
Location & Sao Paulo, Brazil \\
Competitors & Ericsson, Siemens, Motorola, and others
\end{tabular}

As illustrated in Figure 3, Alpha was organized into four divisions of Radio, Transmission, Switching and Wireless Communications Systems respectively; whereas each division was managed by a senior executive who responded to a group of executive directors who responded to Alpha's president. Each division comprised several departments, such as financial, planning, engineering, production, quality assurance, and infrastructure.

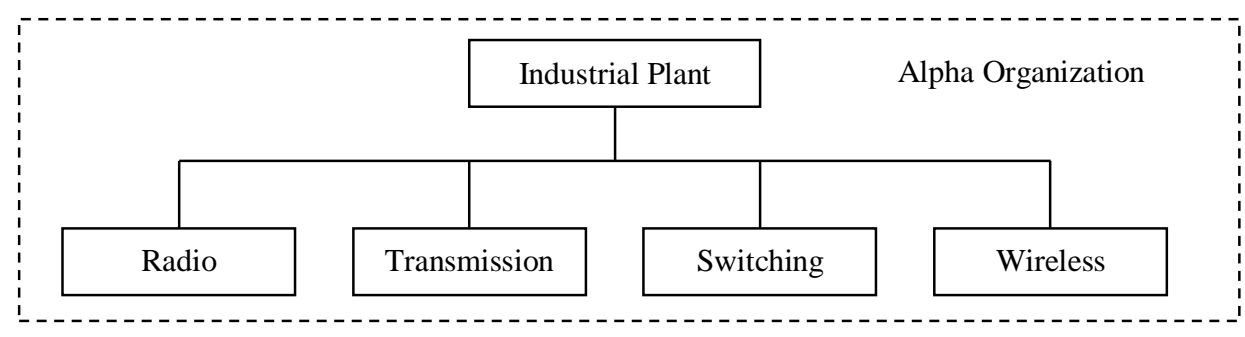

Figure 3. Alpha's Structure.

\section{From strategic business units (SBU) to core competencies and capabilities (CCC): 1996- 1997}

Alpha's pursuit of Total Quality Management (TQM) benefited itself with successful achievements and international certifications, such as ISO 9000 and ISO 14000 during the 1990's. Alpha's four divisions shared experiences, processes and best practices of ISO 9000, ISO 14000, and Just in Time (JIT) systems, along with other concepts of TQM. However, until 1996, each Alpha 
division used to developing its own technical and managerial software capabilities, similarly to Strategic Business Units (SBU) (Prahalad \& Hamel, 1990). Nevertheless, during the 1990's, the demand for Alpha software projects by Brazilian clients as well as by Alpha's worldwide partners had increased to a level of complexity which resulted, in 1996, in Alpha investing in new processes and technologies in order to support and to improve the development of technological, managerial and organizational core competencies and capabilities in its four software units (divisions) seen in Figure 3. This initiative complemented Alpha efforts in the pursuit of Total Quality Management (TQM) and customer satisfaction programs.

After researching the market and consulting experts in partnership with the University of Sao Paulo, Alpha chose the Capability Maturity Model (Carnegie Mellon University, 1994; Chrissis, Konrad, \& Shrum, 2011) in order to develop new software core competencies and capabilities; and to reconfigure itself from Strategic Business Units (SBU) to a portfolio of Core Competencies and Capabilities (CCC). Therefore, from 1997, the Capability Maturity Model (CMM) was carefully examined and tailored in Alpha, resulting in new technical, managerial and organizational routines to support Alpha's software business. The tailoring process contributed to create new tacit and explicit knowledge in the organization.

\section{Developing Alpha's CCC: 1997-2001}

\section{Perceiving the need of CCC's creation}

The need of development of Alpha's new software capabilities was especially perceived by engineers and managers who played technical and managerial roles in Alpha's software units, as well as by marketing executives who worked between Alpha and the external environment. These professionals started to understand the need for software capability growth if they wanted to satisfy stricter criteria in software technology, processes and business. They needed to achieve new customers' requirements, to expand market share and to position Alpha at the frontier of competitive advantage. Proposed plans and ideas for software capability growth were negotiated and approved by other executives and directors who worked at Alpha's upper layers. Subsequently, a circular and continuous flow of CCC's creation was implemented in Alpha; whereas developments in software capability were mostly based on the Capability Maturity Model's guidelines (Carnegie Mellon University, 1994).

\section{Alpha's CCC strategy}

The strategy for tailoring, reconfiguring and implementing the Capability Maturity Model $(\mathrm{CMM})$ in Alpha is illustrated in Figure 4. In this implementation, the CMM guidelines and recommendations were interpreted by an Organizational Software Engineering Process Group (OSEPG) who created a tailoring process to write the Organization's Standard Software Process (OSSP). The OSSP involved a set of managerial and organizational routines of software process improvement which supported Alpha's software units in the development of their Core Competencies and Capabilities (CCC).

The O-SEPG was composed by one top TQM manager and by eight software project experts who were participants in the four software units. In the software units, in turn, Unit Software Engineering Process Groups (U-SEPG) were responsible for tailoring and integrating the OSSP into Project Defined Software Processes (PDSP); whereas PDSP involved a set of technical and managerial Core Competencies and Capabilities (CCC) for software projects. Each U-SEPG involved software project managers and engineers. The PDSP's experiences, data, metrics, routines, sub-routines and best practices were collected in the four software units and stored in Alpha's Data Base by the Organizational Software Engineering Process Group (O-SEPG) with the purpose of sharing, exchanging, disseminating and creating collective knowledge and learning in order to renew and integrate Core Competencies and Capabilities (CCC) across the four Alpha software units. From this 
Alpha CCC strategy, expectations were formed around the enhancement of intelligence, autonomy, learning and knowledge management abilities in the organization.

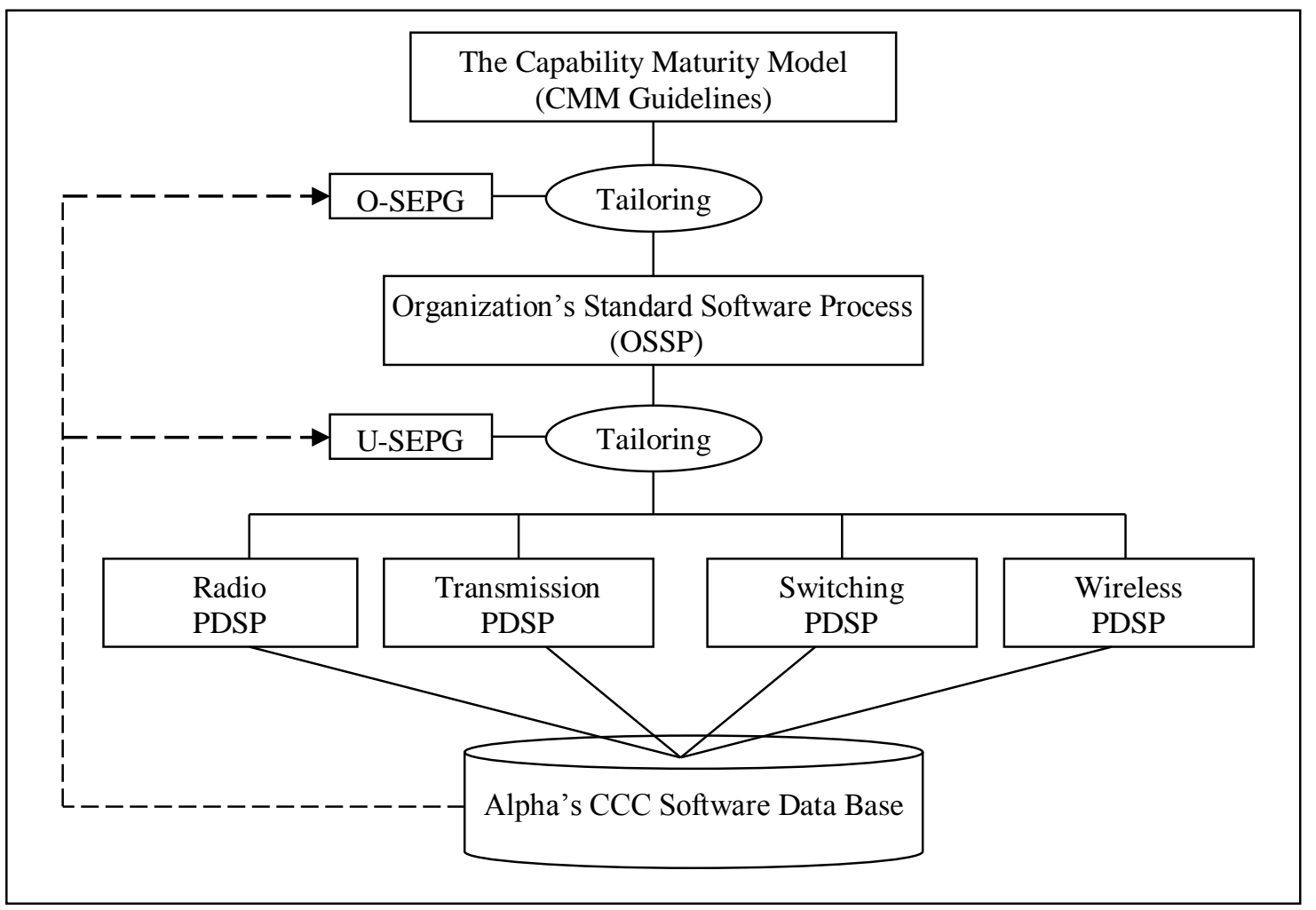

Figure 4. Alpha's CCC Strategy.

\section{Alpha's levels of routines and sub-routines}

Alpha's bottom layer subsumed the technical level and the set of Project Defined Software Processes (PDSP) from Alpha's Radio, Transmission, Switching and Wireless Communications Systems. At this layer, PDSP sub-routines supported managers and engineers mostly with low-order or ordinary capabilities for the development of software projects and products. Alpha's managerial layer mediated between the technical and the organizational levels, and subsumed the Organization's Standardized Software Process (OSSP). At this layer, OSSP routines supported managers and software experts mostly with high-order or dynamic capabilities for the reconfiguration and integration of PDSP sub-routines into new capabilities which better matched the task and overall environments. Changes and decisions at this layer influenced U-SEPG's perceptions and PDSP's sub-routines. Alpha's organizational layer mediated between the organization and the environment. Changes and decisions at this layer influenced O-SEPG and U-SEPG perceptions along with OSSP and PDSP routines and sub-routines.

\section{Alpha's software capabilities}

Alpha's key software capabilities are presented in Table 2. These capabilities are mostly based on CMM guidelines for improving a software process (Carnegie Mellon University, 1994). Capabilities evolve in complexity and elaboration as the organization moves from initial to optimizing levels. 
Table 2

Alpha' Software Capabilities

\begin{tabular}{|c|c|c|}
\hline Maturity/Capability Levels & Purpose & Main Routines \\
\hline 1. Initial & $\begin{array}{l}\text { The software process is characterized as } \\
\text { ad hoc, and occasionally even chaotic. } \\
\text { Few processes are defined, and success } \\
\text { depends on individual effort. }\end{array}$ & $\begin{array}{l}\text { Not applicable, because at this level the } \\
\text { organization has no software process; } \\
\text { or the process is a black-box or } \\
\text { amorphous entity. }\end{array}$ \\
\hline 2. Repeatable & $\begin{array}{l}\text { Basic project management processes } \\
\text { are established in Alpha's software } \\
\text { units in the form of Project's Defined } \\
\text { Software Process (PDSP) to track cost, } \\
\text { schedule, and functionality. The } \\
\text { necessary process discipline is in place } \\
\text { to repeat earlier successes on projects } \\
\text { with similar applications. }\end{array}$ & $\begin{array}{l}\text { Requirements Management } \\
\text { Software Project Planning } \\
\text { Software Project Tracking and } \\
\text { Oversight } \\
\text { Software Subcontract Management } \\
\text { Software Quality Assurance } \\
\text { Software Configuration Management }\end{array}$ \\
\hline 3. Defined & $\begin{array}{l}\text { The software process for both } \\
\text { management and engineering activities } \\
\text { is documented, standardized, and } \\
\text { integrated into an Organization's } \\
\text { Standard Software Process (OSSP). All } \\
\text { projects use a PDSP which is an } \\
\text { approved, tailored version of the OSSP } \\
\text { for developing and maintaining } \\
\text { software. }\end{array}$ & $\begin{array}{l}\text { Organization Process Focus } \\
\text { Organization Process Definition } \\
\text { Training Program } \\
\text { Integrated Software Management } \\
\text { Software Product Engineering } \\
\text { Intergroup Coordination } \\
\text { Peer Reviews }\end{array}$ \\
\hline 4. Managed & $\begin{array}{l}\text { Detailed measures of the software } \\
\text { process and product quality are } \\
\text { collected. Both the software process } \\
\text { and products are quantitatively } \\
\text { understood and controlled. }\end{array}$ & $\begin{array}{l}\text { Software quality management } \\
\text { Quantitative process management }\end{array}$ \\
\hline 5. Optimizing & $\begin{array}{l}\text { Continuous process improvement is } \\
\text { enabled by quantitative feedback from } \\
\text { the process and from piloting } \\
\text { innovative ideas and technologies. }\end{array}$ & $\begin{array}{l}\text { Process change management } \\
\text { Technology change management } \\
\text { Defect prevention }\end{array}$ \\
\hline
\end{tabular}

\section{Operational Definitions of Key Constructs}

\section{Alpha's software capability and performance}

While performance represents actual results achieved by following a process, capability is associated with the levels of process elaboration and complexity. Moreover, literature results have shown that process capability provides an organization with the potential for performance growth (Carnegie Mellon University, 1994).

\section{Assessment of Alpha's software capability: 1997-2001}

Alpha's software capability is associated with the five levels of Table 2. In the period between 1997 and 2001, Alpha's four software units were assessed by an independent group of lead evaluators who were officially authorized by the Software Engineering Institute of Carnegie Mellon University to perform CMM-based assessment. Alpha's four software units were officially recognized for completely satisfying the goals, commitments and activities of levels 2 and 3 of Table 2 . They had not 
satisfied all the requirements of levels 4 and 5, but they were working to achieve the full capabilities at these top levels.

\section{Assessment of Alpha's software performance (ASP): 1997-2001}

Performance assessment was fundamental to investigate whether capability growths would benefit performance. Figure 5 illustrates the management control system used in evaluation of Alpha's Software Performance (ASP) between 1997 and 2001. Based on feedback and learning cycles, this management control was implemented according to principles of single-loop and double-loop learning (Argyris, 1976).

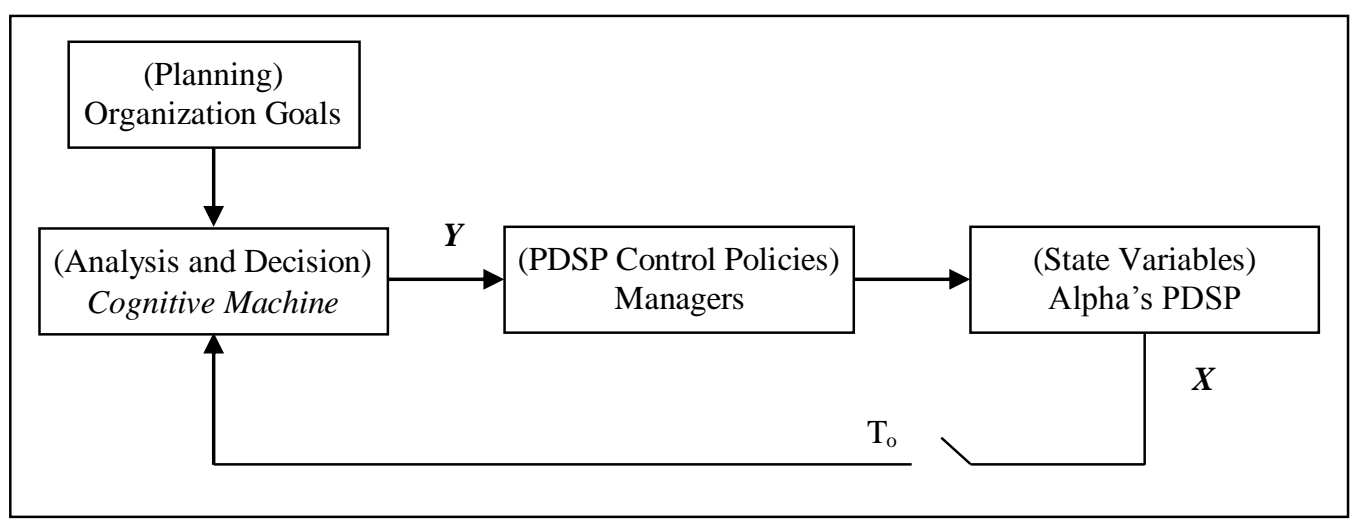

Figure 5. Management Control of Alpha's Software Performance (ASP).

The elements of these management control system included:

1. Planning: This stage involved definitions of criteria, indexes, factors and measures of ASP. Criteria represented the boundaries of targets to be achieved. Indices $(\boldsymbol{Y})$ included Customer Satisfaction (CS) and Project Effectiveness (PE): $\boldsymbol{Y}=(\mathrm{CS}, \mathrm{PE})$, as representations of ASP; indexes were variables dependent on performance factors. Factors $(\boldsymbol{X})$ were represented by Alpha's PDSP state variables and included project cost $(\mathrm{C})$ and project requirements completeness $(\mathrm{R}): \boldsymbol{X}=(\mathrm{C}$, R). Measures were functions $(f)$ that mapped factors (state variables $\boldsymbol{X}$ ) to performance indices $(\boldsymbol{Y})$ :

$$
f: X \rightarrow Y
$$

2. Sampling $\mathbf{T}_{\mathbf{0}}$ : This stage involved the collection of qualitative and quantitative data about the state variables $\boldsymbol{X}=(\mathrm{C}, \mathrm{R})$ of Alpha's PDSP. The sampling time $\left(\mathrm{T}_{\mathrm{o}}\right)$ represented the period of collection of new data about $\boldsymbol{X}$. $\mathrm{T}_{\mathrm{o}}$ was defined as equal to the expected period of time of project completion, which was estimated during the project planning stage.

3. Analysis and Decision: This stage involved computational modeling of Alpha's performance factors and indexes. This block was represented by a function $(f)$ which mapped the factors $\mathrm{C}$ and $\mathrm{R}$ to the performance indexes CS and PE. Analysis and decision tasks were performed by a cognitive machine (Nobre et al., 2009a, 2009b) whose design and analysis are presented in Appendix A. This machine received data about $\boldsymbol{X}=(\mathrm{C}, \mathrm{R})$ at time $\mathrm{T}_{\mathrm{o}}$ in order to compute $\boldsymbol{Y}=(\mathrm{CS}$, $\mathrm{PE})$.

4. Control Policies: This stage subsumed routines and sub-routines which supported managers' decisions in order to improve Alpha's performance indices $\boldsymbol{Y}=(\mathrm{CS}, \mathrm{PE})$. These control policies were mostly based on Alpha's software capabilities from Table 2.

\section{Cognition associated with Alpha's Capability Levels}

Cognition was symbolically associated with tangible and intangible measures of processes and representations, and in particular with the measurement of Alpha's capability level. Therefore, degrees 
of cognition could symbolically assume values in the integer interval [1,5] of capability levels of Table 2. Figure 6 illustrates a symbolic positive relationship between degree of cognition and level of capability. The dotted arrow defines a direct relationship between these variables. As the organization moves from capability levels 1 to 5, its routines, sub-routines and collective knowledge evolve in a continuous path of process improvement.

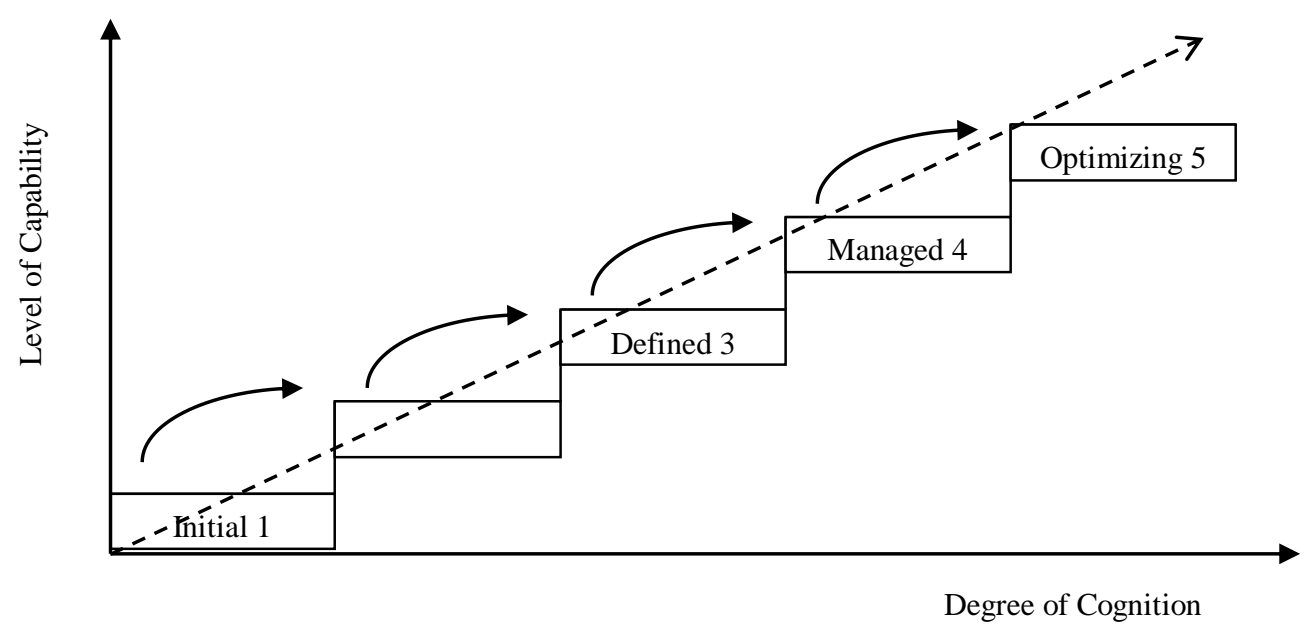

Figure 6. Degree of Cognition vs. Level of Capability Growth.

\section{Analyzing Data and Shaping Hypotheses}

Figure 7 shows the results of Alpha's Software Performance (ASP) for five successive, largescale and discrete Software Projects (SP1,..,SP5) in the period between 1997 and 2001. The continuous real scale $[0,10]$ denotes measurements of Customer Satisfaction (CS) and Project Effectiveness (PE). Moving from projects SP1 to SP5, there was a growth in the levels of CS, PE and ASP.

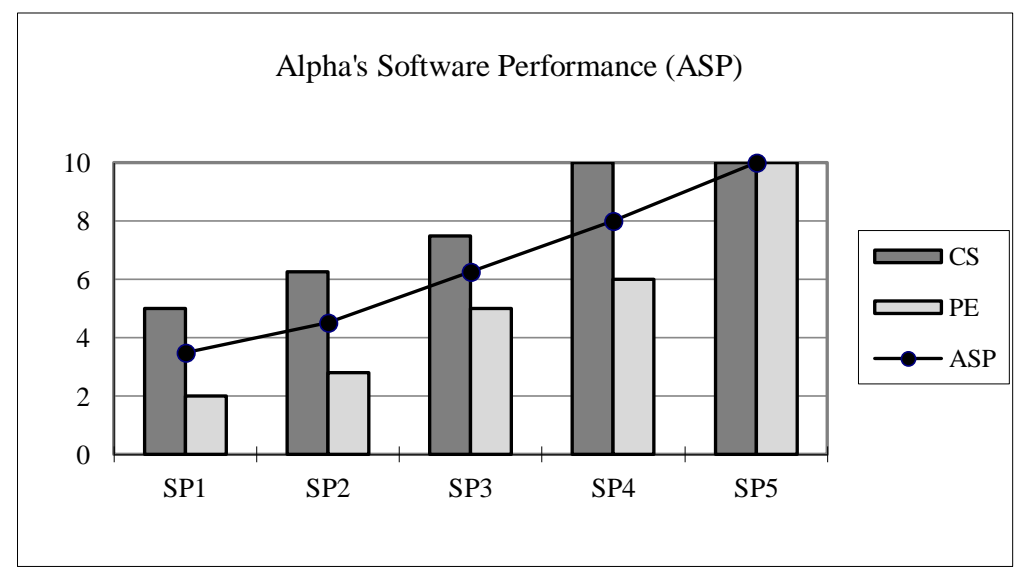

Figure 7. Alpha's Software Performance (ASP).

These results indicated that Alpha's Software Capabilities, especially represented by OSSP and PDSP routines and subroutines, contributed to improve CS, PE and ASP during the study period. 


\section{On capability and performance}

Results demonstrated that improvements in the level of Alpha's Software Performance (ASP) were associated with improvements in the level of Alpha's Software Capability (ASC). These findings corroborated literature results, which showed that process maturity and capability provide organizations with performance growth (Gibson, Golsendon, \& Kost, 2006; Herbsleb, Carleton, Rozum, Siegel, \& Zubrow, 1994; Paulk \& Chrissis, 2002). Therefore, this research states that:

Proposition (P1): The higher the level of capability, the higher the level of performance.

\section{On cognition, capability and performance}

From the symbolic association of degree of cognition with level of capability, and also from proposition ( $\mathrm{P} 1)$, this work states that improvements in the level of capability and performance are associated with improvements in the degree of cognition:

Proposition (P2): The higher the degree of cognition, the higher the level of capability.

Proposition (P3): The higher the degree of cognition, the higher the level of performance.

In this analysis, the degree of cognition was represented in the integer real scale of $[1,5]$ when cognition was associated with capability levels. Additionally, the degree of cognition was represented in the continuous real scale of $[0,10]$ when cognition was associated with Alpha's Software Performance (ASP). Propositions P2 and P3 are also supported by literature findings on the influence of cognition on competitive advantage growth (Nobre \& Walker, 2011a).

\section{On cognition and other abilities}

Figure 7 shows that ASP evolved and described Alpha's learning curve in software process improvement. It also indicates a growth in Alpha's intelligence, since this ability is associated with the degree to which an organization satisfies its goals through rationality. These results also corroborated literature studies which have proposed that cognition contributes to improve intelligence, autonomy, learning and knowledge management levels (Nobre et al., 2010; Nobre \& Walker, 2011a, 2011b). Therefore, this research states that:

Proposition (P4): The greater the degree of cognition, the greater the levels of intelligence, autonomy, learning and knowledge management.

\section{Conclusions}

\section{Reviewing research goals and findings}

This research proposed to find answers to four main questions: (a) What are the antecedents which can provide an organization with dynamic and ordinary capabilities?; (b) How do these antecedents contribute to create capabilities in an organization? (c) How do they affect an organization's competitive advantage? (d) Can we assess and measure the antecedents and consequences to an organization?

Responses to the first, second and third questions were given by reviewing concepts of an ability-based view of the organization that involved cognition, intelligence, autonomy, learning and knowledge management abilities, and a framework which explained the dynamic behavior of the firm in the pursuit of competitive advantage. In this view, abilities represented the antecedents and the source of development of competencies and capabilities. 
Answers to the second, third and fourth questions were reinforced and delivered in the findings of a case study that evidenced the ability-based view in action in a software corporation. The case study investigated three activities in order to answer these questions: (a) the development of capabilities in the organization; (b) the effects of the new capabilities on the organization; and (c) the assessment and measurement of the abilities and consequences.

First (a), the development of capabilities in the organization was based on strategies that reconfigured the company Alpha from Strategic Business Units (SBU) to a portfolio of Core Competencies and Capabilities (CCC). The need for development of new capabilities to match a new environment with stricter software technology, processes and business criteria was first perceived and interpreted by engineers and managers who played technical and managerial roles in Alpha's software units, as well as by marketing executives. This activity involved the creation, integration and reconfiguration of new technical, managerial and organizational routines and sub-routines to support Alpha's software units in software capability and performance growth. In such a study, capabilities evolved in complexity and elaboration as the organization moved from initial to optimizing maturity levels. Best practices, experiences, data, metrics, routines and sub-routines were collected in the four software units and stored in Alpha's Data Base with the purpose of sharing, exchanging, disseminating and creating collective knowledge and learning in order to renew and to integrate Core Competencies and Capabilities (CCC) across Alpha's four software units. From this Alpha CCC strategy, expectations were formed around the enhancement of intelligence, autonomy, learning and knowledge management abilities in the organization.

Second (b), the effects of the new capabilities on the organization were measured through assessments of Alpha's Software Capability (ASC) and Alpha's Software Performance (ASP). ASC was associated with the levels of elaboration and complexity of Alpha's software processes, routines and subroutines. The level of ASC was evaluated according to criteria of CMM-based assessments, which comprised five capability levels from 1 to 5. SCP calculation was supported by data gathered from five successive, large-scale and discrete software projects. ASP was dependent on the concepts and measurements of Customer Satisfaction (CS) and Project Effectiveness (PE), and was represented on the continuous real scale of $[0,10]$. Results of this activity demonstrated that improvements in the ASP level were associated with improvements in the level of ASC. These findings corroborated literature results which showed that process maturity and capability provide organizations with performance growth (Gibson et al., 2006; Herbsleb et al., 1994; Paulk \& Chrissis, 2002). Therefore, this research stated that:

Proposition (P1): The higher the level of capability, the higher the level of performance.

And third (c), the assessment and measurement of the abilities and consequences involved the symbolic association of cognition with tangible and intangible measures of processes and representations, and in particular with the measure of the ASC level. From this symbolic association and proposition ( $\mathrm{P} 1)$, this work stated that improvements in capability and performance were associated with improvements in cognition:

Proposition (P2): The higher the degree of cognition, the higher the level of capability.

Proposition (P3): The higher the degree of cognition, the higher the level of performance.

Therefore, the degree of cognition could be represented in the integer real scale of $[1,5]$ when cognition was associated with capability levels. Additionally, the degree of cognition could be represented in the continuous real scale of $[0,10]$ when cognition was associated with Alpha's Software Performance (ASP). Propositions P2 and P3 are also supported by literature findings on the influence of cognition on competitive advantage growth (Nobre \& Walker, 2011a); whereas, in this research, Alpha's competitive advantage is interpreted as ASC and ASP.

Improvements evidenced by ASP's curve also represented the growth in Alpha's learning and intelligence. These results also corroborated literature studies which have proposed that cognition 
contributes to improve the levels of intelligence, autonomy, learning and knowledge management (Nobre et al., 2010; Nobre \& Walker, 2011a, 2011b). Therefore, this research reinforced that:

Proposition (P4): The greater the degree of cognition, the greater the levels of intelligence, autonomy, learning and knowledge management.

\section{Limitation and future research}

One limitation in this work concerned the research methodology of a single case study which restricted the use of cross-case comparisons and cross-case pattern search (Eisenhardt, 1989; Eisenhardt \& Graebner, 2007). Therefore, this work recognizes the importance of development of new research on the ability-based view which involves multiple-case studies in order to find a stronger base for theory building.

\section{References}

Argyris, C. (1976). Single-loop and double-loop models in research on decision making. Administrative Science Quarterly, 21(3), 363-375.

Argyris, C., \& Schön, D. A. (1978). Organizational learning: a theory of action perspective. Reading, MA: Addison-Wesley.

Barney, J. (1991). Firm resources and sustained competitive advantage. Journal of Management, 17(1), 99-120. doi: 10.1177/014920639101700108

Barney, J., Ketchen, D. J., Jr., \& Wright, M. (2011). The future of resource-based theory: revitalization or decline? Journal of Management, 37(5), 1299-1315. doi: $10.1177 / 0149206310391805$

Brewer, M. B., \& Hewstone, M. (2004). Social cognition. Oxford, UK: Blackwell Publishing.

Carnegie Mellon University. (1994). The capability maturity model: guidelines for improving the software process. Reading, MA: Addison-Wesley.

Chrissis, M. B., Konrad, M., \& Shrum, S. (2011). CMMI: guidelines for process integration and product improvement. Reading, MA: Addison-Wesley.

Collis, J., \& Hussey, R. (2009). Business research: a practical guide for undergraduate and postgraduate students. New York: Palgrave McMillan.

Eden, C. (1992). On the nature of cognitive maps. J. of Management Studies, 29(3), 261-265. doi: $10.1111 / j .1467-6486.1992 . t b 00664 . x$

Eden, C. (2004). Analyzing cognitive maps to help structure issues or problems. European Journal of Operational Research, 159(3), 673-686. doi: 10.1016/S0377-2217(03)00431-4

Eisenhardt, K. M. (1989). Building theories from case study research. Academy of Management Review, 14(4), 532-550. doi: 10.5465/AMR.1989.4308385

Eisenhardt, K. M., \& Graebner, M. E. (2007). Theory building from cases: opportunities and challenges. Academy of Management Journal, 50(1), 25-32. doi: 10.5465/AMJ.2007.24160888

Eisenhardt, K. M., \& Martin, J. A. (2000). Dynamic capabilities: what are they? Strategic Management Journal, 2l(10/11), 1105-1121. doi: 10.1002/10970266(200010/11)21:10/11<1105::AID-SMJ133>3.0.CO;2-E 
Fiol, C. M., \& Huff, A. S. (1992). Maps for managers: where are we? Where do we go from here? Journal of Management Studies, 29(3), 267-285. doi: 10.1111/j.1467-6486.1992.tb00665.x

Flyvbjerg, B. (2006). Five misunderstandings about case-study research. Qualitative Inquiry, 12(2), 219-245. doi: 10.1177/1077800405284363

Gavetti, G. (2005). Cognition and hierarchy: rethinking the microfoundations of capabilities' development. Organization Science, 16(6), 599-617. doi: 10.1287/orsc.1050.0140

Gibson, D. L., Golsendon, D. R., \& Kost, K. (2006). Performance results of CMMI-Based process improvement. Pittsburg: Carnegie Mellon University.

Grant, R. M. (1996). Toward a knowledge-based theory of the firm (Special Issue). Strategic Management Journal, 17, 109-122.

Helfat, C. E., \& Peteraf, M. A. (2003). The dynamic resource-based view: capability lifecycles. Strategic Management Journal, 24(10), 997-1010. doi: 10.1002/smj.332

Helfat, C. E., \& Peteraf, M. A. (2009). Understanding dynamic capabilities: progress along a developmental path. Strategic Organization, 7(1), 91-102. doi: 10.1177/1476127008100133

Helfat, C. E., \& Winter, S. G. (2011). Untangling dynamic and operational capabilities: strategy for the (N)ever-changing world. Strategic Management Journal, 32(11), 1243-1250. doi: $10.1002 / \mathrm{smj} .955$

Herbsleb, J. D., Carleton, A., Rozum, J. A., Siegel, J., \& Zubrow, D. (1994). Benefits of CMM-based software process improvement: executive summary of initial results. Pittsburg: Carnegie Mellon University.

Hitt, M. A., Ireland, R. D., \& Hoskisson, R. E. (2012). Strategic management: competitiveness and globalization, concepts and cases. Cincinnati, OH: South-Western Cengage Learning.

Klir, G. J., \& Folger, T. A. (1988). Fuzzy sets, uncertainty, and information. Englewood Cliffs, N.J: Prentice Hall.

Laamanen, T., \& Wallin, J. (2009). Cognitive dynamics of capability development paths. Journal of Management Studies, 46(6), 950-981. doi: 10.1111/j.1467-6486.2009.00823.x

Lei, D., Hitt, M. A., \& Bettis, R. (1996). Dynamic core competences through meta-learning and strategic context. Journal of Management, 22(4), 549-569. doi: 10.1177/014920639602200402

Leiblein, M. J. (2011). What do resource- and capability-based theories propose? Journal of Management, 37(4), 909-932. doi: 10.1177/0149206311408321

March, J. G. (1991). Exploration and exploitation in organizational learning. Organization Science, 2(1), 71-87. doi: $10.1287 /$ orsc.2.1.71

March, J. G., \& Simon, H. A. (1958). Organizations. New York: John Wiley \& Sons.

Nicolini, D. (1999). Comparing methods for mapping organizational cognition. Organization Studies, 20(5), 833-860. doi: 10.1177/0170840699205006

Nobre, F. S. (2012, August). Contributions of fuzzy logic and bounded rationality to cognitive machines in organizations. Proceedings of the Annual NAFIPS Meeting (North American Fuzzy Information Processing Society), Berkeley, CA, USA, 31.

Nobre, F. S., Nakasone, J. J., Palhares, A. B., Madrid, M. K., \& Roy, R. (2000, August). Fuzzy logic in management control: a case study. Proceedings of the IEEE Engineering Management Society, Albuquerque-NM, USA. 
Nobre, F. S., Tobias, A. M., \& Walker, D. (2009a). Organizational and technological implications of cognitive machines: designing future information management systems. New York: IGI Global.

Nobre, F. S., Tobias, A. M., \& Walker, D. (2009b). The impact of cognitive machines on complex decisions and organizational change. Journal of AI and Society, 24(3), 365-381. doi: 10.1007/s00146-009-0207-4

Nobre, F. S., Tobias, A. M., \& Walker, D. S. (2010). A new contingency view of the organization: managing complexity and uncertainty through cognition. Brazilian Administration Review, 7(4), 379-396. Retrieved from http://www.scielo.br/pdf/bar/v7n4/05.pdf. doi: 10.1590/S180776922010000400005

Nobre, F. S., \& Walker, D. S. (2011b). A dynamic ability-based view of the organization. International Journal of Knowledge Management, 7(2), 86-101. doi: 10.4018/jkm.2011040105

Nobre, F. S., \& Walker, D. S. (2011a). An ability-based view of the organization: strategic-resource and contingency domains. The Learning Organization, 18(4), 333-345. doi: $10.1108 / 09696471111132531$

Nobre, F. S., Walker, D. S., \& Harris, R. (2012). Technological, managerial and organizational core competencies: dynamic innovation and sustainable development. New York: IGI Global.

Paulk, M. C., \& Chrissis, M. B. (2002). The 2001 high maturity workshop. Pittsburg: Carnegie Mellon University.

Pavlou, P. A., \& El Sawy, O. A. (2011). Understanding the elusive black box of dynamic capabilities. Decision Sciences Journal, 42(1), 239-273. doi: 10.1111/j.1540-5915.2010.00287.x

Pedrycz, W., \& Gomide, F. (2007). Fuzzy systems engineering: toward human-centric computing. New Jersey: John Wiley \& Sons.

Pettus, M. L., Kor, Y. Y., \& Mahoney, J. T. (2009). A theory of change in turbulent environments: the sequencing of dynamic capabilities following industry deregulation. Int. J. Strategic Change Management, 1(3), 186-211.

Prahalad, C. K., \& Hamel, G. (1990). The core competence of the corporation. Harvard Business Review, 68(3), 79-91.

Prietula, M. J., Carley, K., \& Gasser, M. (1998). Simulating organizations: computational models of institutions and groups. Menlo Park, CA: AAAI Press / MIT Press.

Scherbaum, C. A., \& Meade, A. W. (2013). New directions for measurement in management research. International Journal of Management Reviews, 15(2), 132-148. doi: 10.1111/ijmr.12003

Schreyögg, G., \& Kliesch-Eberl, M. (2007). How dynamic can organizational capabilities be? Towards a dual-process model of capability dynamization. Strategic Management Journal, 28(9), 913-933. doi: 10.1002/smj.613

Scott, W. R. (1998). Organizations: rational, natural, and open systems. Upper Saddle River, NJ: Prentice Hall.

Simon, H. A. (1977). The new science of management decision. Upper Saddle River, NJ: Prentice Hall.

Simon, H. A. (1997a). Administrative behavior: a study of decision-making processes in administrative organizations. New York: The Free Press. 
Simon, H. A. (1997b). Models of bounded rationality: empirically grounded economic reason (Vol. 3). Cambridge, MA: MIT Press.

Sirmon, D. G., Hitt, M. A., Ireland, R. D., \& Gilbert, B. A. (2011). Resource orchestration to create competitive advantage: breadth, depth, and life cycle effects. Journal of Management, 37(5), 1390-1412. doi: 10.1177/0149206310385695

Spender, J. C. (1996). Making knowledge the basis of a dynamic theory of the firm (Special Issue). Strategic Management Journal, 17, 45-62. doi: 10.2307/2486990

Teece, D. J. (2007). Explicating dynamic capabilities: the nature and microfoundations of (sustainable) enterprise performance. Strategic Management Journal, 28(13), 1319-1350. doi: 10.1002/smj.640

Teece, D. J., Pisano, G., \& Shuen, A. (1997). Dynamic capabilities and strategic management. Strategic Management Journal, 18(7), 509-533. doi: 10.1002/(SICI)10970266(199708)18:7<509::AID-SMJ882>3.0.CO;2-Z

Tidd, J. (2006). From knowledge management to strategic competence - measuring technological, market and organizational innovation. London: Imperial College Press.

Tripsas, M., \& Gavetti, G. (2000). Capabilities, cognition, and inertia: evidence from digital imaging. Strategic Management Journal, 21(10/11), 1147-1161. doi: 10.1002/10970266(200010/11)21:10/11<1147::AID-SMJ128>3.0.CO;2-R

Volpe, R., Nobre, F. S., Pessoa, M., \& Spinola, M. (2000, August). The role of software process improvement into TQM: an industrial experience. Proceedings of the IEEE Engineering Management Society, Albuquerque-NM, USA.

Wang, L. (1994). Adaptive fuzzy systems and control: design and stability analysis. Englewood Cliffs, NJ: Prentice-Hall.

Wang, C. L., \& Ahmed, P. K. (2007). Dynamic capabilities: a review and research agenda. International Journal of Management Reviews, 9(1), 31-51. doi: 10.1111/j.14682370.2007.00201.x

Winter, S. J. (2003). Understanding dynamic capabilities. Strategic Management Journal, 24(10), 991995. doi: $10.1002 / \mathrm{smj} .318$

Yin, R. K. (2011). Qualitative research from start to finish. New York: The Guilford Press.

Zadeh, L. A. (1973). Outline of a new approach to the analysis of complex systems and decision process. IEEE Transactions on Systems, Man, and Cybernetics, 3(1), 28-44. doi: 10.1109/TSMC.1973.5408575

Zadeh, L. A. (1999). From computing with numbers to computing with words - from manipulation of measurements to manipulation of perceptions. IEEE Transactions on Circuits and Systems, 45(1), 105-119. doi: 10.1109/81.739259

Zadeh, L. A. (2001). A new direction in AI: toward a computational theory of perceptions. AI Magazine, 22(1), 73-84. doi: 10.1609/aimag.v22i1.1545 


\section{APPENDIX}

\section{Design and Analysis of the Cognitive Machine}

This appendix summarizes the design of the cognitive machine (Nobre et al., 2009a; 2009b) which supported the assessment of Alpha's Software Performance (ASP).

\section{Structure}

Figure A1 illustrates the basic structure of the cognitive machine.

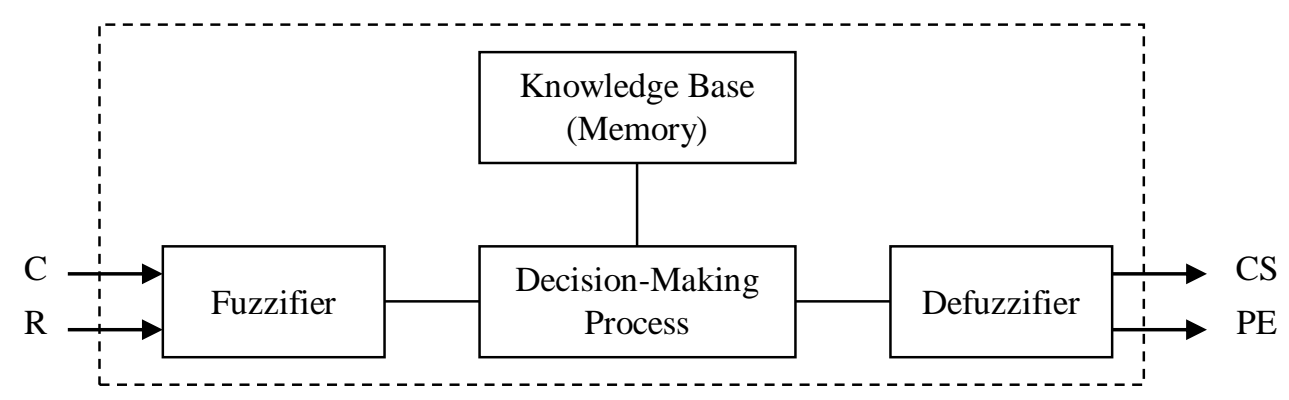

Figure A1. Cognitive Machine’s Structure.

\section{Criteria of design}

The set of design criteria of the cognitive machine is presented in Table A1. These criteria involve concepts which are defined by the literature on fuzzy systems (Klir \& Folger, 1988; Pedrycz \& Gomide, 2007; Wang 1994).

Table A1

\section{Cognitive Machine Design Criteria}

Criteria L1: The fuzzy sets of the input variables satisfy the definition of fuzzy numbers and fuzzy partitions.

Criteria L2: The fuzzy sets of the output variables satisfy the definition of fuzzy numbers and their center contains only one element.

Criteria L3: The rule base (or the set of fuzzy conditional statements) satisfies the definition of strict completeness.

Criteria L4: The AND logical operator is implemented as the algebraic product.

Criteria L5: The OR logical operator is implemented as the bounded sum.

Criteria L6: The implication function satisfies the criteria of fuzzy conjunction and it is implemented as the algebraic product.

Criteria L7: The singleton fuzzifier is the operator defined to the fuzzification of input variables.

Criteria L8: The centre average defuzzifier is the operator defined to the defuzzification of output variables.

The adoption of Criteria L1 to L8 resulted in a cognitive machine whose algorithm can be modeled and implemented in computers, and most importantly, investigated through stability analysis (Nobre et al., 2009a; Wang, 1994). Moreover, criterion L3 guarantees that for all input states of $\boldsymbol{X}=$ 
$(\mathrm{C}, \mathrm{R})$, there exists an output state of $\boldsymbol{Y}=(\mathrm{CS}, \mathrm{PE})$. The specification of the cognitive machine's functional blocks is presented in the next subsections.

\section{Description of percepts via words and linguistic variables}

Linguistic variables assume linguistic values and they involve descriptions of percepts and concepts via words (Nobre, 2012; Zadeh, 1973, 1999). In such a design, the input (C and R) and output variables (CS and PE) assume a set of linguistic values. Their granularity and concepts were defined according to the experience of the cognitive machine designer along with the expertise of $\mathrm{O}$ SEPG and U-SEPG's members that participated in the focus group.

. Input Variables

$\mathrm{C}=($ cheap, not so cheap, expensive); $\mathrm{R}=$ (empty, almost empty, partial, almost full, full).

. Output Variables

$\mathrm{CS}=($ very low, low, medium, high, very high).

$\mathrm{PE}=$ (really bad, very bad, bad, moderate, good, very good, really good).

\section{Representation of concepts via membership functions of fuzzy sets}

Membership functions of fuzzy sets (Zadeh, 1973) are mathematical representations of linguistic variables, percepts and natural concepts (Nobre, 2012; Nobre et al., 2009a). The representations of the input (C and $\mathrm{R})$ and output variables (CS and PE) via fuzzy sets are illustrated in Figures A2 and A3 respectively. They were defined according to Criteria L1 and L2. Their triangular shape and universe of discourse were specified according to the experience of the cognitive machine designer along with the expertise of O-SEPG and U-SEPG's participants. In Figure A2, $\mu_{C}$ and $\mu_{R}$ denote the degrees of membership of $C$ and $R$ in their respective fuzzy sets, for $\mu_{C}$ and $\mu_{R} \in[0,1]$. Co and Ro denote values of planning cost and planning requirements completeness which were estimated at the software projects' planning stage. The words cheap, not so cheap and expensive are labels of fuzzy sets which characterize the concept of cost (C) defined on the universe of discourse C; and the words empty, almost empty, partial, almost full and full are labels of fuzzy sets which characterize the concept of requirements completeness $(\mathrm{R})$ defined in the universe of discourse $\mathrm{R}$.

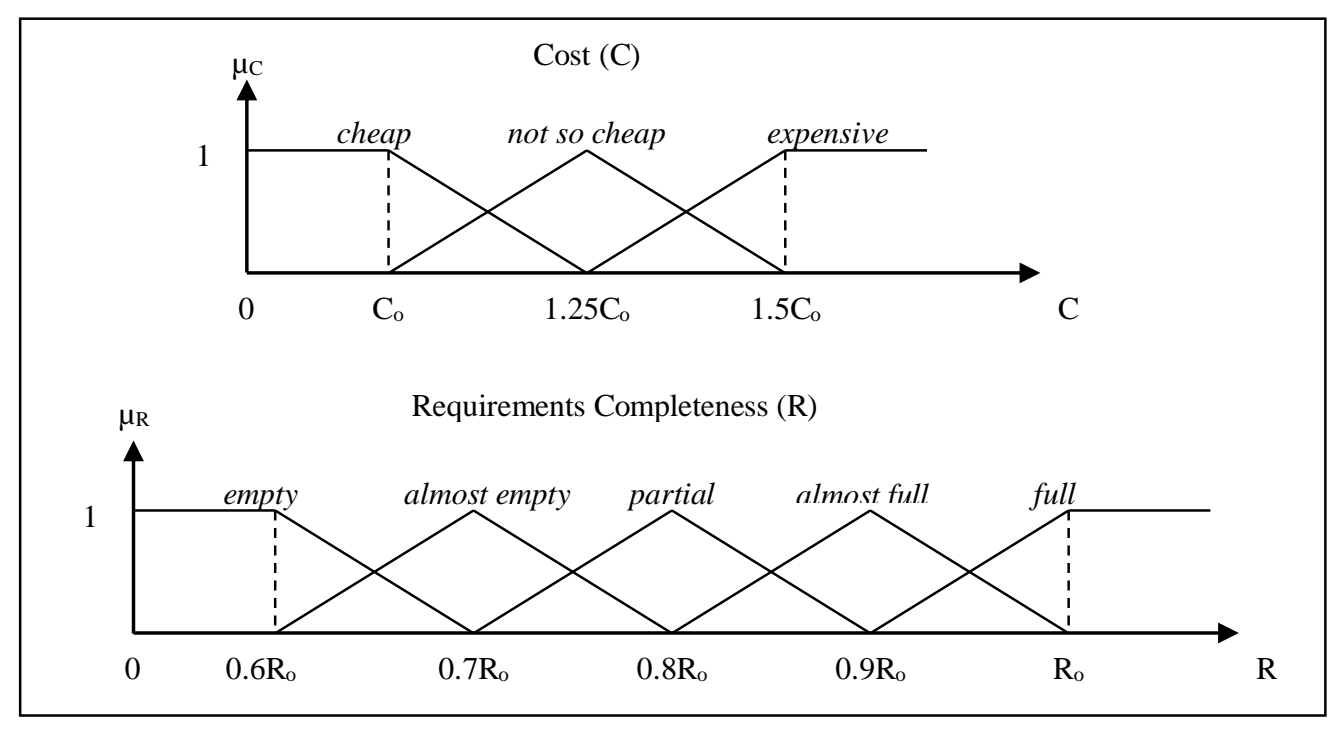

Figure A2. Fuzzy Sets of $X=(C, R)$. 
In Figure A3, $\mu_{\mathrm{CS}}$ and $\mu_{\mathrm{PE}}$ denote the degrees of membership of CS and PE in their respective fuzzy sets, for $\mu_{\mathrm{CS}}$ and $\mu_{\mathrm{PE}} \in[0,1]$. The words very low, low, medium, high and very high are labels of fuzzy sets which characterize the concept of Customer Satisfaction (CS) defined in the universe of discourse CS; and the words really bad, very bad, bad, moderate and good, very good and really good are labels of fuzzy sets which characterize the concept of Project Effectiveness (PE) defined in the universe of discourse PE.

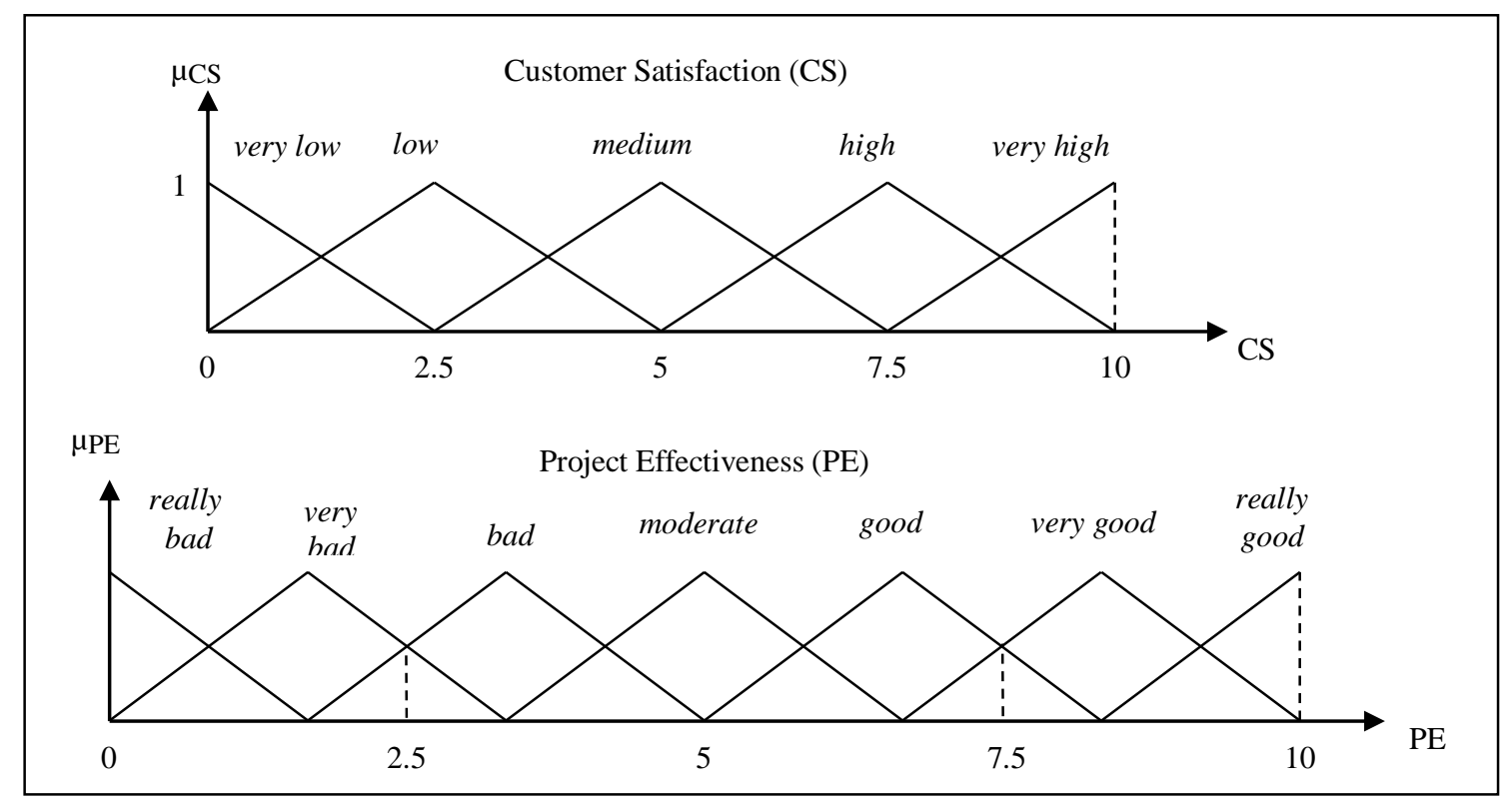

Figure A3. Fuzzy Sets of $\mathrm{Y}=(\mathrm{CS}, \mathrm{PE})$.

\section{Representation of mental models via fuzzy conditional statements}

Fuzzy conditional statements describe relations between two or more linguistic variables in the form of Zadeh (1999):

IF A THEN B: $(A \rightarrow B)$

$A$ and $B$ denote linguistic or fuzzy variables; the operator THEN denotes fuzzy implication $(A \rightarrow B)$; and the symbol $\rightarrow$ denotes implication function (Zadeh, 1973). Fuzzy conditional statements are important approaches to perception-based system modeling (Zadeh, 2001). In this paper, fuzzy conditional statements are representations of clusters of propositions and mental models which describe the relationships between input $\boldsymbol{X}=(\mathrm{C}, \mathrm{R})$ and output $\boldsymbol{Y}=(\mathrm{CS}, \mathrm{PE})$ variables. They were written according to the experience of the cognitive machine designer along with the expertise of $\mathrm{O}$ SEPG and U-SEPG's participants.

\section{Linguistic fuzzy rule bases}

The set of fuzzy conditional statements resulted in two linguistic fuzzy rule bases which satisfied Criterion L3. One rule base described relations between R and CS, and another described relations between $\mathrm{C}, \mathrm{R}$ and $\mathrm{PE}$ :

Fuzzy Rule Base 1: IF R THEN CS: $(R \rightarrow C S)$

Fuzzy Rule Base 2: IF C AND IF R THEN PE: (C AND $R \rightarrow P E)$

The operator AND satisfied Criterion L4 and the implication function $(\rightarrow)$ satisfied L6. 
On one side, project cost (C) was not included in the Fuzzy Rule Base 1 because this variable is not a concern for customers. On the other side, project cost (C) was included in the Fuzzy Rule Base 2 because it is a control variable in project effectiveness.

The set of fuzzy conditional statements of Fuzzy Rule Bases 1 and 2 are represented in Figures A4 and A5 respectively. Their aggregation or union satisfied Criterion L5.

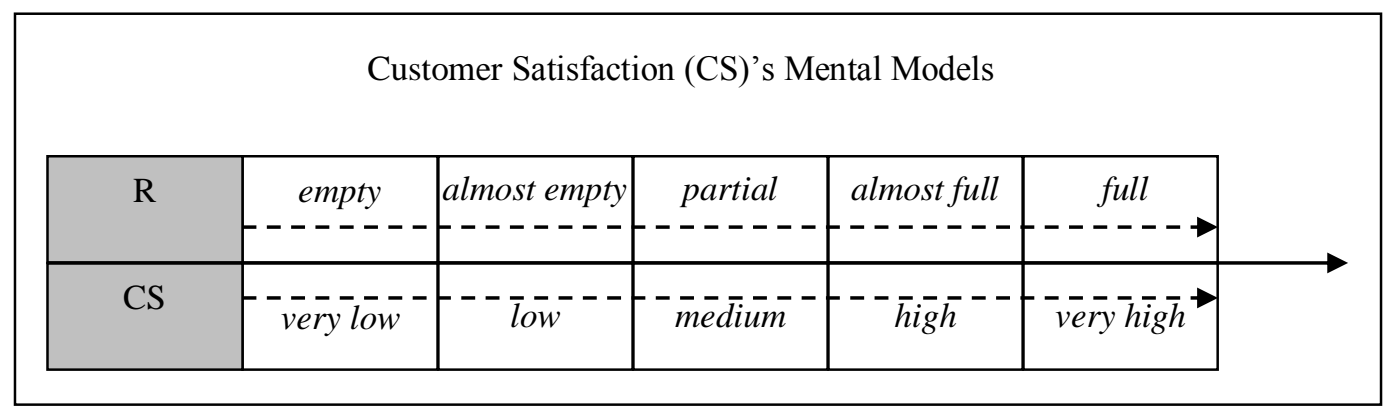

Figure A4. Mental Models about Customer Satisfaction: $\mathrm{R} \rightarrow \mathrm{CS}$.

In Figure A4, the cells above and below the horizontal axis contain the linguistic values of $\mathrm{R}$ and CS respectively. The fuzzy conditional statements are symbolically represented by the pairs of cells constituted by the linguistic values of R and CS. This rule base comprises a set of five fuzzy conditional statements. The first pair of cells which linguistic values are in the front of $\mathrm{R}$ and CS forms one linguistic fuzzy conditional statement defined by:

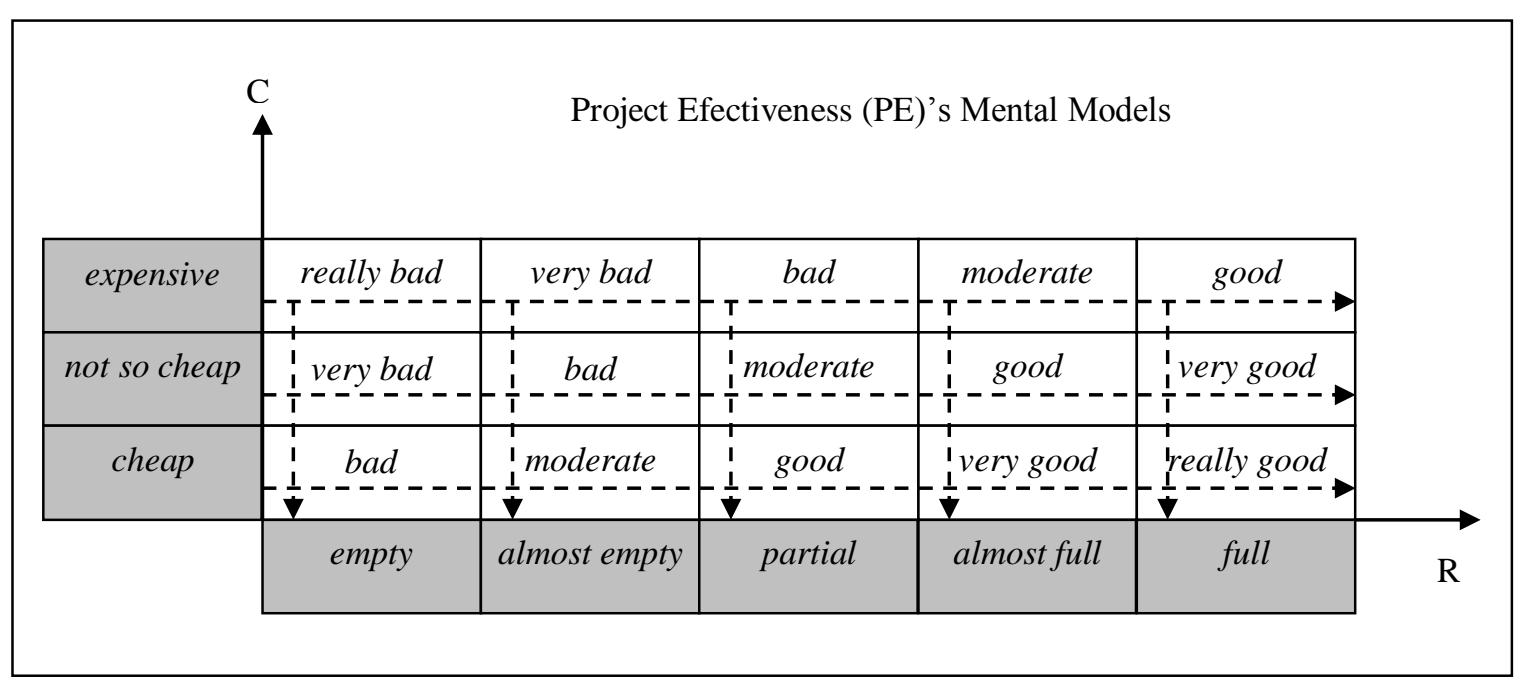

Figure A5. Mental Models about Project Effectiveness: (C AND R) $\rightarrow$ PE.

In Figure A5, the cells on the left side of the vertical axis contain the linguistic values of $\mathrm{C}$ and those cells below the horizontal axis contain the linguistic values of $\mathrm{R}$. The other cells, located in between the $\mathrm{C}$ and $\mathrm{R}$ axes (in the first quadrant) contain the linguistic values of $\mathrm{PE}$ which represent the conclusions of the fuzzy conditional statements. This rule base comprises a set of fifteen fuzzy conditional statements. As an example, when the variables $\mathrm{C}$ and $\mathrm{R}$ assume the respective linguistic values of not so cheap and full, then PE assumes the linguistic value of very good. This linguistic fuzzy conditional statement is described as: 


\section{Decision-making via the compositional rule of inference}

The compositional rule of inference of fuzzy logic (Zadeh, 1973, 1999) was the mechanism used to implement the decision-making process of the cognitive machine. This mechanism of inference manipulates concepts (and thus percepts) by propagating them from premises (antecedents) of fuzzy conditional statements to conclusions. It can also be defined as a mechanism to reason with linguistic representations of mental models (Zadeh, 2001).

\section{Qualitative analysis}

The qualitative analysis of the cognitive machine was proposed in (Nobre et al., 2009a). The qualitative analysis is concerned about the study of the cognitive machine's linguistic rules which represent mental models about the relations between $\boldsymbol{X}=(\mathrm{C}, \mathrm{R})$ and output $\boldsymbol{Y}=(\mathrm{CS}, \mathrm{PE})$. This analysis is based on the concept of linguistic phase plane which state space and cells are represented with linguistic values as illustrated in Figures A4 and A5. It contributes with a methodology to construct the initial set of fuzzy rules as well as to visualize and to modify these rules. Figure A4 illustrates a linguistic phase plane of one dimension which characterizes the relations between the linguistic variables ( $\mathrm{R}$ and $\mathrm{CS}$ ) and their respective linguistic values. The dotted arrows indicate the directions of growth in the linguistic values of R and CS. From Figure A4, we conclude that the higher the linguistic value of $\mathrm{R}$ is, the higher the linguistic value of CS, because the higher the completion of project requirements $(\mathrm{R})$ at time $\mathrm{T}_{\mathrm{o}}$ is, the higher the Customer Satisfaction (CS). Figure A5 illustrates a linguistic phase plane of two dimensions that characterizes the relations between the linguistic variables $(\mathrm{C}, \mathrm{R}$ and $\mathrm{CS})$ and their respective linguistic values. The dotted arrows indicate the directions of growth in the linguistic values of Project Effectiveness (PE). From this Figure A5, we conclude that the higher the linguistic value of $\mathrm{R}$ is, the higher the linguistic value of $\mathrm{PE}$, because the higher the completion of project requirements $(\mathrm{R})$ at time $\mathrm{T}_{\mathrm{o}}$ is, the higher the PE. Moreover, Figure A5 indicates that the higher the linguistic value of $\mathrm{C}$ is, the lower the linguistic value of $\mathrm{PE}$, because the higher the project cost (C) at time $\mathrm{T}_{\mathrm{o}}$ is, the lower Project Effectiveness (PE). 